\title{
The association between breastfeeding and childhood obesity: a meta-analysis
}

\author{
Jing Yan', Lin Liu², Yun Zhu², Guowei Huang ${ }^{3^{*}}$ and Peizhong Peter Wang ${ }^{2,4^{*}}$
}

\begin{abstract}
Background: The increase in childhood obesity is a serious public health concern. Several studies have indicated that breastfed children have a lower risk of childhood obesity than those who were not breastfed, while other studies have provided conflicting evidence. The objective of this meta-analysis was to investigate the association between breastfeeding and the risk of childhood obesity.

Methods: The PubMed, EMBASE and CINAHL Plus with Full Text databases were systematically searched from start date to $1^{\text {st }}$ August 2014. Based on the meta-analysis, pooled adjusted odds ratio (AOR) and 95\% confidence interval (Cl) were calculated. $I^{2}$ statistic was used to evaluate the between-study heterogeneity. Funnel plots and Fail-safe $\mathrm{N}$ were used to assess publication bias and reliability of results, and results from both Egger test and Begg test were reported.
\end{abstract}

Results: Twenty-five studies with a total of 226,508 participants were included in this meta-analysis. The studies' publication dates ranged from 1997 to 2014, and they examined the population of 12 countries. Results showed that breastfeeding was associated with a significantly reduced risk of obesity in children ( $A O R=0.78 ; 95 \% \mathrm{Cl}: 0.74$, 0.81). Categorical analysis of 17 studies revealed a dose-response effect between breastfeeding duration and reduced risk of childhood obesity.

Conclusion: Results of our meta-analysis suggest that breastfeeding is a significant protective factor against obesity in children.

Keywords: Breastfeeding, Children, Obesity, Meta-analysis

\section{Background}

Obesity has become a major public health crisis around the world. Since overweight and obesity are strongly correlated with diseases such as diabetes, hypertension, high cholesterol, cardiovascular diseases, stroke, arthritis, and certain types of cancers, the number of obesity-related death is estimated at 2.8 million per year [1,2]. Childhood obesity has also dramatically worsened and is now considered a major threat to human health [3-5]. According to the International Obesity Taskforce (IOTF) [1] and the World Health Organization (WHO) [6,7], there are more than 200 million overweight or obese

\footnotetext{
* Correspondence: huangguowei@tmu.edu.cn; pwang@mun.ca

${ }^{3}$ Department of Nutrition and Food Science, School of Public Health, Tianjin Medical University, Tianjin 300070, China

${ }^{2}$ Division of Community Health and Humanities, Faculty of Medicine, Memorial University of Newfoundland, St. John's, Newfoundland and Labrador A1B 3 V6, Canada

Full list of author information is available at the end of the article
}

children throughout the world and, in 2010, over 42 million children under age of 5 were classified as overweight. Unfortunately, childhood obesity is linked to several physical and mental health conditions, including orthopedic problems, menstruation problems, sleep trouble, depression, anxiety and diabetes in childhood $[8,9]$. Moreover, overweight/obese children are more likely to be obese in adulthood [10].

Childhood obesity has multiple causes, including genetic factors, personal behaviors (e.g., exercise, sleep duration, and TV viewing), dietary habits, and their interactions [11-14], and many researchers have investigated various possible interventions to prevent childhood obesity. Among these, breastfeeding has been associated with a decreased risk of obesity, along with other health benefits for the child and mother. According to the WHO recommendations, infants should be exclusively breastfed for the first 6 months, and breastfeeding should be supplemented with additional 
foods for the first 2 years (or beyond) [15]. Breast milk is considered the ideal food for infants, as it provides adequate energy and nutrients to meet the infants' needs. In addition, as breast milk is safe and contains antibodies, breastfeeding could reduce the risk of neonatal infection, gastrointestinal infection, and pneumonia during infancy $[9,10]$. It has been indicated that approximately $45 \%$ of neonatal infectious deaths, $30 \%$ of diarrhoeal death and $18 \%$ of respiratory death among children $<5$ years old are associated with suboptimal breastfeeding [15]. Moreover, breastfeeding has long-term benefits throughout a child's lifetime. Children and adults who were breastfed have lower rates of overweight/obese, type- 2 diabetes, hypertension, and are known score higher on intelligence tests than persons who were formula-fed [12,15]. Based on the WHO report, if every child in the world was exclusively breastfed for the first 6 months, followed by breastfeeding until 2 years, the lives of 800,000 children would be saved each year [16]. Additionally, breastfeeding protects mothers against breast cancer, ovarian cancer, and obesity. Exclusive breastfeeding also is an effective, natural method of birth control, providing $98 \%$ protection between birth and 6 months postpartum [15].

In 2012, approximately $38 \%$ of infants who were under 6 months old were exclusively breastfed worldwide [15], with additional feeding methods including partial breastfeeding and exclusively formula feeding $[9,12]$. The major factors that affect prevalence and duration of breastfeeding include maternal race/ethnicity, education, breast diseases, inadequate breast milk production, employment, length of maternity leave, inadequate knowledge regarding breastfeeding, lack of familial and societal support, and lack of guidance and encouragement from health care professionals $[9,15]$. To strengthen breastfeeding practices, families, employers, professional workers and society as a whole should fully support to breastfeeding mothers.

Over the previous decade, a growing body of research has indicated an association between breastfeeding and childhood obesity. Breastfeeding has been identified as a protective factor for childhood obesity in many studies [16-20], while other studies failed to establish an association between the breastfeeding and childhood obesity $[21,22]$. Three previous reviews have addressed this issue, the latest one being published about 9 years ago in 2005 [23-25]. Arenz et al. [23] included 9 studies that focused on the relationship between breastfeeding and childhood obesity with adjusted odds ratio (AOR). Owen et al. [24] presented the pooled odds ratio (OR) for 28 studies reporting the effects of infant feeding on the risk of obesity, as well as the pooled AOR for 6 studies that adjusted for socioeconomic status, parental body mass index (BMI), and maternal smoking. Lastly, Harder et al. analyzed the relationship between the duration of the breastfeeding and overweight based on 17 studies [25].
Given the lack of recent reviews, we conducted a systematic review to assess the association between breastfeeding and childhood obesity, and to explore the nature of the association. Compared to the previous reviews [23-25], this analysis is different in both eligibility criteria and study methodologies. We reviewed all studies that published until $1^{\text {st }}$ August 2014 to generate an updated and extended data set and used AOR and 95\% confidence interval (CI) to control for potential confounders. Moreover, the prevalence of breastfeeding is changing, and there are unique trends emerging in different countries. For example, the prevalence of breastfeeding is increasing in the UK [26], while the prevalence of exclusive breastfeeding is declining in China [27]. Thus, this review provides important updated data to reflect the changing of breastfeeding throughout the world.

\section{Methods}

\section{Literature search}

The search strategy was comprised of the following steps: 1) formulation of the main topic, and inclusion and exclusion criteria; and 2) literature search, including both electronic databases, hand-search of key journals (e.g., Obesity, International Journal of Obesity, Pediatric Obesity, International Journal of Pediatric Obesity) and the references from the retrieved papers. We systematically searched the following databases: PubMed, EMBASE and CINAHL Plus with Full Text databases. The following keywords were used: (breastfed*) AND (obesity OR overweight OR adiposity) AND (child* OR infant). The publication language was restricted to English and Chinese, and the publication date was up to $1^{\text {st }}$ August 2014 with no lower date limit. All retrieved articles were screened according to predefined inclusion and exclusion criteria (described below) by two authors. Any disagreement was resolved in discussion with the project lead.

\section{Study selection}

Studies were included if they fulfilled the following eligibility criteria: evaluated the relationship between breastfeeding and obesity; provided AOR with 95\% CI for the association of obesity with breastfeeding; reported potential confounding factors, defined obesity and/or overweight, and breastfeeding type; and included study subjects older than 1 year. Studies were excluded on the basis of the following criteria: focused on other disease; were duplicates; provided incomplete data (e.g., no AOR, 95\% CI) or insufficient data for calculation of these estimates; did not provide data on BMI; were not published as full text; were not primary research (e.g., reviews, commentaries, consultants' corners, letters, conference abstracts). If the same study sample was used in 2 or more studies, findings of the largest sample size or the longest follow-up periods were included. Two investigators independently completed the 
literature search and selection procedures. If a discrepancy occurred regarding article selection, the 2 authors would discuss or refer to other authors.

\section{Data extraction}

A standardized form was used to extract data independently by 2 authors. The following information from each article was extracted: first author, publication year, study design, study population characteristics of country, ethnicity, age, feeding patterns (e.g., never-ever breastfeeding, breastfeeding duration), BMI, sample size, and data provided such as AOR or data used to calculate the AOR, corresponding 95\% CI, and confounding factors (e.g., birth weight, gender, age, maternal overweight, maternal smoking, maternal education, socioeconomic status, dietary habits, exercise). Disagreements between the 2 authors were resolved by discussion or referred to other authors.

\section{Obesity and breastfeeding definition}

We used BMI, which was calculated by dividing the individual's weight (in kilograms) by the square of their height (in meters), as an index of obesity [28]. As there were no standard BMI cutoffs to label obesity or overweight in children, the definitions of obesity were not uniform across eligible studies. The IOTF defined overweight or obesity as BMI $\geq 25 \mathrm{~kg} / \mathrm{m}^{2}$ or $\geq 30 \mathrm{~kg} / \mathrm{m}^{2}$ [28-30]; several studies used a BMI percentiles as the cutoff values of obesity, including BMI $\geq 95^{\text {th }}$ or BMI $\geq 97^{\text {th }}$ percentile [29]; and other variables to define the cutoff, for example, BMI $\geq 90^{\text {th }}$, BMI $\geq 94^{\text {th }}$, BMI >2 standard deviations (SD), and Chinese children's BMI cutoffs of obesity (Boys' BMI $\geq 96.3^{\text {th }}$, Girls' BMI $\geq 98^{\text {th }}$ ). The calculation of BMI for child and adolescent population was the same as that for adults; however, childhood obesity (age under 20 years) was defined by comparing with children of the same sex and age $[28,29]$. Given these diverse criteria for obesity, we considered whether they might affect the accuracy of our estimate, and conducted sensitivity analysis to evaluate the influence.

Data were categorized according to various breastfeeding variables, and information regarding breastfeeding was typically obtained from the parents. Several studies grouped infants into "ever breastfed" versus "never breastfed", or "exclusively breastfed" versus "mixed fed" versus "exclusively formula fed". Ever breastfeeding was defined as any attempt at breastfeeding, even if only for a short time; never breastfeeding was defined as no breastfeeding; exclusively breastfeeding was defined as breastfeeding without supplementation (e.g., no solid food, tea, herbal preparation or liquids); mixed feeding was defined as a combination of breastfeeding and formula feeding; and exclusively formula feeding was defined as only formula feeding $[15,23]$. Other studies classified children in terms of the duration of breastfeeding, which was measured in weeks or months. Therefore, we stratified the included articles for the subgroup analysis as never-ever breastfeeding (i.e., ever breastfed versus never breastfed, exclusively breastfed versus exclusively formula fed) and breastfeeding duration. Studies using exclusive breastfeeding versus mixed feeding versus exclusive formula feeding were grouped into the never-ever breastfeeding category.

\section{Statistical analysis}

Based on the aforementioned eligibility criteria, data on AOR and 95\% CI were extracted from each included study. We calculated the $\mathrm{I}^{2}$ statistics $(0 \% \sim 100 \%)$ to explain the between-study heterogeneity, with $\mathrm{I}^{2} \leq 25 \%$ suggesting more homogeneity, $25 \%<\mathrm{I}^{2} \leq 75 \%$ suggesting moderate heterogeneity, and $\mathrm{I}^{2}>75 \%$ suggesting high heterogeneity [31,32]. If the null hypothesis was rejected, a random effects model was used to calculate pooled effect estimates [33]. If the null hypothesis was not rejected, a fixed effects model was used to calculate pooled effect estimates [33]. Sensitivity analysis was performed to assess how results vary by study design, definitions of obesity and breastfeeding, type of breastfeeding, and adjustment for potential confounding factors. Publication bias was assessed first with the funnel plot $[34,35]$, followed by formal statistical tests. The funnel plot graphically checked the existence of publication bias in meta-analyses. Egger test and Begg test were reported with a $p<0.05$ being considered statistically significant, in order to avoid limitations of the funnel plot [36-38]. Reliability of results were examined for each job satisfaction predictor though Fail-safe N. All analyses were performed using Comprehensive Meta Analysis Version 2.2.064, provided by Biostat.

\section{Results}

\section{Study selection and characteristics}

The comprehensive literature search of electronic databases, key journals, and cross-references yielded 718 publications, which included 428 unduplicated articles, regarding the association between obesity and breastfeeding published before $1^{\text {st }}$ August 2014 as potentially relevant articles. A total of 25 studies with 226,508 subjects [39-63] were included in the present meta-analysis. The publication dates for these studies ranged from 1997 to 2014, and involved the population of 12 countries, including 5 German studies, 5 American studies, 3 British studies, 3 Australian studies, 2 Chinese studies, 1 Japanese study, 1 Irish study, 1 Greek study, 1 Brazilian study, 1 Dutch study, 1 Czech study, and 1 Canadian study. Of these, 24 included studies published in English and 1 study in Chinese. Ten studies were cross-sectional surveys and 15 were cohort studies, which included 10 prospective cohort studies and 5 indicate historical cohort studies. The selection process is detailed in Figure 1. 
The description of the included studies is provided in Table 1. Six of the 25 studies defined overweight and obesity according to the IOTF recommendation $[45,47,49,52,57,58], 10$ studies defined overweight as BMI $\geq 85^{\text {th }}$ percentile and obesity as BMI $\geq 95^{\text {th }}$ percentile according to the criteria developed by the Centers of Disease Control and Prevention (CDC) [39,42-44,46,50,53,54,60,61], 5 studies defined overweight and obesity according to the German reference as BMI $\geq 90^{\text {th }}$ percentile and $\geq 97^{\text {th }}$ percentile $[40,41,48,59,62]$, and 4 studies defined obesity alternatively as BMI $\geq 90^{\text {th }}$ percentile, BMI $\geq 94^{\text {th }}$ percentile, BMI $>2 \mathrm{SD}$, and the Chinese children's BMI cut-off for obesity $[51,55,56,63]$.

\section{Main meta-analysis results}

The pooled AOR derived from all 25 studies was 0.78 (95\% CI: 0.74, 0.81) and the details are presented in a Forest plot (Figure 2). There was no significant heterogeneity across studies $\left(I^{2}=45.28 \%, P<0.01\right)$, and the studies met fixed effects model. Additionally, we analyzed unadjusted data of results. Sixteen studies [39,40,43,45-47,51,52,55$60,62,63]$ presented information on the crude ORs, and the pooled crude OR and the corresponding 95\% CIs are shown in Figure 3 with a forest plot. The pooled OR was 0.61 (95\% CI: $0.55,0.68)$. The homogeneity hypothesis was rejected $\left(I^{2}=65.40 \%, P<0.01\right)$, and hence the studies met random effected meta-analysis criteria.

\section{Sensitivity analysis}

Sensitivity analysis was carried out to evaluate differences in study design, definitions of obesity and breastfeeding, type of breastfeeding, and adjustment for potential confounding factors (Table 2). Findings suggested that studies that classified children using the breastfeeding duration showed a more protective effect of breastfeeding against childhood obesity than other studies. The 6 studies that applied the IOTF definition of obesity, showed weaker associations between breastfeeding and childhood obesity, than studies that defined childhood obesity as BMI $\geq 95^{\text {th }}$, $\mathrm{BMI} \geq 97^{\text {th }}$ or other standards. Moreover, there was no difference between the pooled estimates across cohort studies and cross-sectional studies. Additionally, our results showed slightly effects of breastfeeding type, and whether the data were adjusted for the confounders, amount of watching TV and exercise in children. In addition, we performed a sensitivity analysis by removing 1 study, and found that the pooled AOR remained largely unchanged $(\mathrm{AOR}=0.78,95 \%$ CI: 0.74, 0.81).

\section{Publication bias}

The funnel plot presented an asymmetric pattern (Figure 4), and the results of Egger test $(\mathrm{p}=0.16)$ and Begg test $(\mathrm{p}=$ 0.25 ) were not statistical significant. The result of Fail-safe $\mathrm{N}\left(\mathrm{N}_{\mathrm{fs} 0.05}=939.78\right)$ indicated high reliability of results. Therefore, we cannot completely exclude potential publication bias.

\section{Breastfeeding duration}

Seventeen studies analyzed the association between breastfeeding duration and obesity, and 9 of these studies presented 2 or more categories for breastfeeding durations. A total of 51 estimates included in the meta-analysis were categorized as $<3$ months, $3-5$ months, $5-7$ months and $\geq 7$ months (Table 3). The length of breastfeeding period was associated with a decreased risk of childhood obesity. Children breastfed for $\geq 7$ months were significantly less likely to be obese (AOR $=0.79,95 \% \mathrm{CI}$ : 0.70 , 0.88 ), while those breastfed for $<3$ months showed about $10 \%$ decrease in the risk of childhood obesity. In addition, we observed a stepwise gradient of decreasing risk of

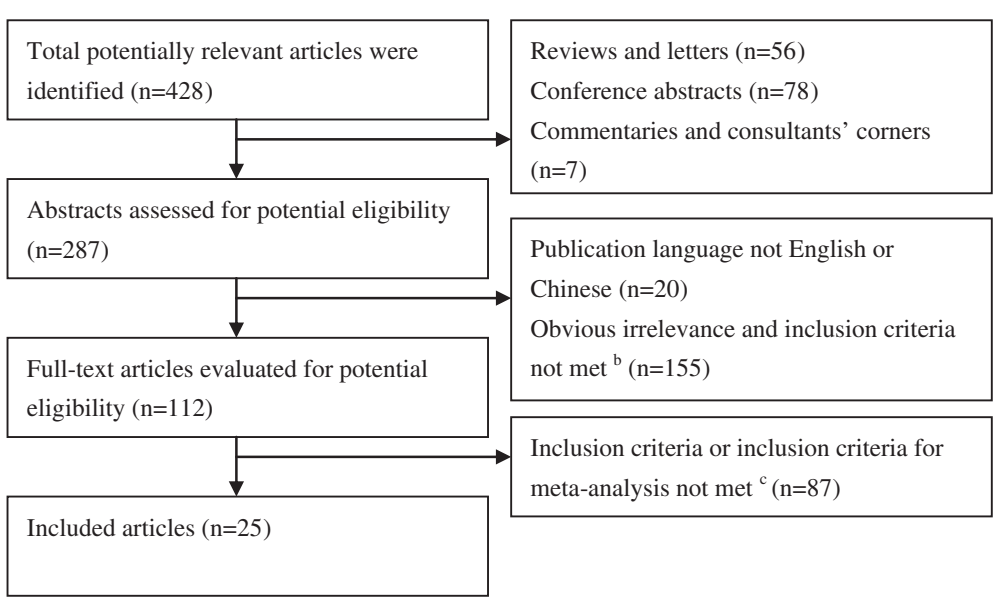

Figure 1 Flowchart of literature search and selection process ${ }^{a} .{ }^{a}$ Please contact the corresponding author for detailed search strategy. ${ }^{b}$ The study did not focus on childhood obesity, breastfeeding, or the relationship between breastfeeding and childhood obesity. The study provided

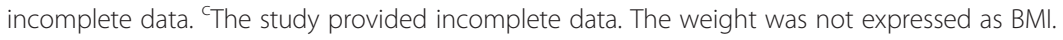


Table 1 Characteristics of included studies in the meta-analysis

\begin{tabular}{|c|c|c|c|c|c|c|c|}
\hline Reference & Origin & $\begin{array}{l}\text { Study } \\
\text { design }\end{array}$ & Age & $\begin{array}{l}\text { Sample } \\
\text { size }^{a}\end{array}$ & $\begin{array}{l}\text { Definition of feeding } \\
\text { patterns }\end{array}$ & $\begin{array}{l}\text { Definition } \\
\text { of obesity }\end{array}$ & Confounders \\
\hline $\begin{array}{l}\text { Armstrong } \\
2002[39]\end{array}$ & $\begin{array}{l}\text { Great } \\
\text { Britain }\end{array}$ & $\mathrm{IHC}$ & $\begin{array}{l}39-42 \\
\text { months }\end{array}$ & 32,200 & Formula-fed, BF & $\mathrm{BMI} \geq 95^{\text {th }}$ & Gender, birth weight, SES \\
\hline $\begin{array}{l}\text { Bergmann } \\
2003[40]\end{array}$ & Germany & $P C$ & 6 years & 480 & Bottle-fed, BF & $\mathrm{BMI} \geq 97^{\text {th }}$ & Overweight mother, SES \\
\hline $\begin{array}{l}\text { Beyerlein } \\
2008[41]\end{array}$ & Germany & CS & $\begin{array}{l}54-88 \\
\text { months }\end{array}$ & 9,368 & Never \& ever BF & $\mathrm{BMI} \geq 97^{\text {th }}$ & $\begin{array}{l}\text { Weight gain from birth to years of life, maternal } \\
\text { BMI, parents' graduate } \mathrm{e}^{\mathrm{c}}\end{array}$ \\
\hline $\begin{array}{l}\text { Burke } 2005 \\
{[42]}\end{array}$ & Australia & $P C$ & $\begin{array}{l}1-8 \\
\text { years }\end{array}$ & 1,672 & $\begin{array}{l}\text { Never, } \mathrm{BF} \leq 4 \mathrm{mo} \\
\mathrm{BF} \leq 8 \mathrm{mo}, \mathrm{BF} \leq 12 \mathrm{mo} \\
\mathrm{BF}>12 \mathrm{mo}\end{array}$ & $\mathrm{BMI} \geq 95^{\text {th }}$ & $\begin{array}{l}\text { Birth weight, gestational age, ethnicity, sex, } \\
\text { maternal BMl, first child, and maternal education }\end{array}$ \\
\hline $\begin{array}{l}\text { Gillman } 2001 \\
{[43]}\end{array}$ & $\begin{array}{l}\text { United } \\
\text { States }\end{array}$ & CS & $\begin{array}{l}9-14 \\
\text { years }\end{array}$ & 14,377 & $\begin{array}{l}\text { Mostly or only fed } \\
\text { formula, mostly or } \\
\text { only BF }\end{array}$ & $\mathrm{BMI} \geq 95^{\text {th }}$ & $\begin{array}{l}\text { Age, sex, birth weight, birth order, Tanner stage, } \\
\text { exercises, daily energy intake, mother's BMl, and } \\
\text { household income, dietary restraint, weight cycling, } \\
\text { and weight concerns }{ }^{\text {bc }}\end{array}$ \\
\hline $\begin{array}{l}\text { Grummer- } \\
\text { Strawn } 2004 \\
\text { [44] }\end{array}$ & $\begin{array}{l}\text { United } \\
\text { States }\end{array}$ & $\mathrm{IHC}$ & 4 years & 12,587 & $\begin{array}{l}\text { Never, } \mathrm{BF}<1 \mathrm{mo} \\
\mathrm{BF} \leq 2.9 \mathrm{mo}, \mathrm{BF} \leq 5.9 \mathrm{mo} \\
\mathrm{BF} \leq 11.9 \mathrm{mo}, \mathrm{BF} \geq 12 \mathrm{mo}\end{array}$ & $\mathrm{BMI} \geq 95^{\text {th }}$ & $\begin{array}{l}\text { Gender, race/ethnicity, birth weight, and mother's } \\
\text { age, education, prepregnancy BMI, and weight gain } \\
\text { during pregnancy c }\end{array}$ \\
\hline $\begin{array}{l}\text { Hawkins } 2009 \\
\text { [45] }\end{array}$ & $\begin{array}{l}\text { Great } \\
\text { Britain }\end{array}$ & PC & 3 years & 13,172 & $\begin{array}{l}\text { Never, } \mathrm{BF}<4 \mathrm{mo}, \\
\mathrm{BF} \geq 4 \mathrm{mo}\end{array}$ & IOTF & $\begin{array}{l}\text { Birth weight, gender, ethnicity, introduction of solid } \\
\text { foods, maternal SES, education, lone motherhood } \\
\text { status, age at first live birth, number of children, } \\
\text { household income, parental overweight, country, } \\
\text { et al. }{ }^{\text {bc }}\end{array}$ \\
\hline $\begin{array}{l}\text { Hediger } 2001 \\
\text { [46] }\end{array}$ & $\begin{array}{l}\text { United } \\
\text { States }\end{array}$ & CS & $\begin{array}{l}3-5 \\
\text { years }\end{array}$ & 2,656 & Never \& ever EBF & $\mathrm{BMI} \geq 95^{\text {th }}$ & $\begin{array}{l}\text { Birth weight, race/ethnicity, gender, age group, } \\
\text { mother's BMI, timing of introduction to solid foods }\end{array}$ \\
\hline Jwa 2014 [47] & Japan & PC & $\begin{array}{l}1.5-8 \\
\text { years }\end{array}$ & 41,572 & $\begin{array}{l}\text { Formula feeding, mixed } \\
\text { feeding, EBF }\end{array}$ & IOTF & $\begin{array}{l}\text { Birth weight, having elder sibling(s), maternal } \\
\text { educational level, age and total house-hold } \\
\text { income at } 0.5 \text { years old }{ }^{c}\end{array}$ \\
\hline $\begin{array}{l}\text { Koletzko } 2009 \\
{[48]}\end{array}$ & Germany & CS & $\begin{array}{l}5-6 \\
\text { years }\end{array}$ & 9,357 & Never \& ever BF & $\mathrm{BMI} \geq 97^{\text {th }}$ & $\begin{array}{l}\text { Parental education, low birth weight, own } \\
\text { bedroom, frequent consumption of butter }{ }^{c}\end{array}$ \\
\hline $\begin{array}{l}\text { Kwok } 2010 \\
{[49]}\end{array}$ & $\begin{array}{l}\text { Hong } \\
\text { Kong }\end{array}$ & PC & 7 years & 7,026 & $\begin{array}{l}\text { Never, partially or } E B F<3 \\
\text { mo, EBF } \geq 3 \text { mo }\end{array}$ & IOTF & $\begin{array}{l}\text { Sex, birth weight, gestational age, birth order, } \\
\text { mother's age at birth, birthplace, number of } \\
\text { hospital admissions at } 0-3 \text { months, parental } \\
\text { education, occupation, income }{ }^{c}\end{array}$ \\
\hline Li 2003 [50] & $\begin{array}{l}\text { Great } \\
\text { Britain }\end{array}$ & CS & $\begin{array}{l}4-18 \\
\text { years }\end{array}$ & 2,631 & $\begin{array}{l}\text { Never, } \mathrm{BF} \leq 1 \mathrm{mo}, \mathrm{BF} \leq 3 \\
\mathrm{mo}, \mathrm{BF} \leq 6 \mathrm{mo}, \mathrm{BF} \leq 9 \\
\mathrm{mo}, \mathrm{BF}>9 \mathrm{mo}\end{array}$ & $\mathrm{BMI} \geq 95^{\text {th }}$ & Sex, parent's BMI, birth weight, and social class ${ }^{c}$ \\
\hline $\begin{array}{l}\text { Liese } 2001 \\
{[51]}\end{array}$ & Germany & CS & $\begin{array}{l}9-10 \\
\text { years }\end{array}$ & 2,108 & Formula-fed, BF & $\mathrm{BMI}>90^{\text {th }}$ & $\begin{array}{l}\text { Age, gender, city, nationality, SES, number of } \\
\text { siblings }^{c}\end{array}$ \\
\hline $\begin{array}{l}\text { McCrory } 2012 \\
{[52]}\end{array}$ & $\begin{array}{l}\text { Republic } \\
\text { of } \\
\text { Ireland }\end{array}$ & $\mathrm{IHC}$ & 9 years & 7,798 & $\begin{array}{l}\text { Never, } \mathrm{BF} \leq 4 \mathrm{wk}, \mathrm{BF} \leq 8 \\
w k, \mathrm{BF} \leq 12 \mathrm{wk}, \mathrm{BF} \leq 25 \\
w k, \mathrm{BF} \geq 26 \mathrm{wk}\end{array}$ & IOTF & $\begin{array}{l}\text { Dietary quality, exercise, maternal education, } \\
\text { gestational age, nationality, weight status, } \\
\text { household income }\end{array}$ \\
\hline $\begin{array}{l}\text { Moschonis } \\
2008[53]\end{array}$ & Greek & $\mathrm{IHC}$ & $\begin{array}{l}1-5 \\
\text { years }\end{array}$ & 2,374 & $\begin{array}{l}\text { Exclusive formula-fed, } \\
\text { mixed, EBF }\end{array}$ & $\mathrm{BMI} \geq 95^{\text {th }}$ & $\begin{array}{l}\text { Parental education, weight status, maternal } \\
\text { gestational diabetes mellitus, alcohol consumption } \\
\text { patterns during pregnancy, age at birth, birth rank }{ }^{c}\end{array}$ \\
\hline $\begin{array}{l}\text { Moss } 2014 \\
{[54]}\end{array}$ & $\begin{array}{l}\text { United } \\
\text { States }\end{array}$ & PC & $\begin{array}{l}2-4 \\
\text { years }\end{array}$ & 14,150 & Never \& ever BF & $\mathrm{BMI} \geq 95^{\text {th }}$ & $\begin{array}{l}\text { Maternal education, maternal age, maternal race, } \\
\text { family poverty, children's birth weight and gender }\end{array}$ \\
\hline $\begin{array}{l}\text { Novaes } 2011 \\
{[55]}\end{array}$ & Brazilian & CS & $\begin{array}{l}6-10 \\
\text { years }\end{array}$ & 764 & Never \& ever BF & $\mathrm{BMI}>2 \mathrm{SD}$ & $\begin{array}{l}\text { Gender, physical education classes, siblings, } \\
\text { maternal nutritional state during pregnancy }{ }^{\text {bc }}\end{array}$ \\
\hline $\begin{array}{l}\text { O'Challaghan } \\
1997[56]\end{array}$ & Australia & PC & 5 years & 2,034 & $\begin{array}{l}\text { Formula fed, } \mathrm{BF} \geq 6 \mathrm{mo} \\
\text { exclusiveness unclear }\end{array}$ & $\mathrm{BMI} \geq 94^{\text {th }}$ & $\begin{array}{l}\text { Birth weight, gander, small for gestational age, } \\
\text { feeding problems, sleeplessness, parental BMI, } \\
\text { maternal education, household income }\end{array}$ \\
\hline $\begin{array}{l}\text { Scholtens } \\
2008[57]\end{array}$ & Dutch & PC & 8 years & 2,043 & $\begin{array}{l}\text { Never, } \mathrm{BF} \leq 16 \mathrm{wk} \\
\mathrm{BF}>16 \mathrm{wk}\end{array}$ & IOTF & $\begin{array}{l}\text { Maternal education, overweight, diet at } 7 \text { years of } \\
\text { age } \mathrm{e}^{\mathrm{bc}}\end{array}$ \\
\hline $\begin{array}{l}\text { Scott } 2012 \\
{[58]}\end{array}$ & Australia & $\mathrm{IHC}$ & $\begin{array}{l}9-16 \\
\text { years }\end{array}$ & 2,066 & $\begin{array}{l}\text { Never, } \mathrm{BF}<2 \mathrm{mo} \\
\mathrm{BF}<4 \mathrm{mo}, \mathrm{BF}<6 \mathrm{mo},\end{array}$ & IOTF & $\begin{array}{l}\text { Age, gender, energy intake, physical activity, sleep } \\
\text { duration, maternal age, education, ethnicity }\end{array}$ \\
\hline
\end{tabular}


Table 1 Characteristics of included studies in the meta-analysis (Continued)

\begin{tabular}{|c|c|c|c|c|c|c|c|}
\hline $\begin{array}{l}\text { Toschke } 2002 \\
\text { [59] }\end{array}$ & $\begin{array}{l}\text { Czech } \\
\text { Republic }\end{array}$ & CS & $\begin{array}{l}6-14 \\
\text { years }\end{array}$ & 33,768 & Never \& ever BF & $\mathrm{BMI} \geq 97^{\text {th }}$ & $\begin{array}{l}\text { Parental education and obesity, birth weight, sports } \\
\text { outside school, number of siblings }{ }^{\text {bc }}\end{array}$ \\
\hline $\begin{array}{l}\text { Twells } 2010 \\
{[60]}\end{array}$ & Canada & CS & 4 years & 1,026 & $\begin{array}{l}\text { formula feeding } \geq 3 \mathrm{mo} \\
\text { mixed feeding } \geq 3 \mathrm{mo} \\
E B F \geq 3 \mathrm{mo}\end{array}$ & $B M I \geq 95^{\text {th }}$ & $\begin{array}{l}\text { Birth weight, gender, age, maternal education, } \\
\text { whether the baby was preterm or full term }{ }^{c}\end{array}$ \\
\hline $\begin{array}{l}\text { Van Rossem } \\
2010[61]\end{array}$ & $\begin{array}{l}\text { United } \\
\text { States }\end{array}$ & $P C$ & 3 years & 884 & $\begin{array}{l}\text { Never, any } B F<6 \mathrm{mo}, \\
\text { partial } \mathrm{BF} \geq 6 \mathrm{mo} \\
\mathrm{EBF} \geq 6 \mathrm{mo}\end{array}$ & $\mathrm{BMI} \geq 95^{\text {th }}$ & $\begin{array}{l}\text { Age, sex, maternal educational, race, BMl, } \\
\text { pregnancy weight gain, birth weight, gestational } \\
\text { age }^{c}\end{array}$ \\
\hline $\begin{array}{l}\text { Von Kries } \\
1999[62]\end{array}$ & Germany & CS & $\begin{array}{l}5-6 \\
\text { years }\end{array}$ & 9,206 & $\begin{array}{l}\text { Never, } \mathrm{EBF} \leq 2 \mathrm{mo}, \mathrm{EBF} \leq \\
5 \mathrm{mo}, \mathrm{EBF} \leq 12 \mathrm{mo} \\
\mathrm{BF}>12 \mathrm{mo}\end{array}$ & $\mathrm{BMI} \geq 97^{\text {th }}$ & $\begin{array}{l}\text { Parental education, low birth weight, own } \\
\text { bedroom, consumption of butter }{ }^{c}\end{array}$ \\
\hline $\begin{array}{l}\text { Zhao } 2013 \\
\text { [63] }\end{array}$ & China & PC & $\begin{array}{l}2- \\
8.4 \text { years }\end{array}$ & 1,189 & $\begin{array}{l}\text { Formula feeding, mixed } \\
\text { feeding, EBF }\end{array}$ & $\begin{array}{l}\text { Boys' BMl } \\
\geq 96.3^{\text {th }} \\
\text { Girls } \mathrm{BMl} \\
\geq 98^{\text {th }}\end{array}$ & $\begin{array}{l}\text { Maternal weight and BMI before pregnancy, } \\
\text { maternal weight increase and the level of blood } \\
\text { glucose during pregnancy, gender, birth weight, } \\
\text { father weight }\end{array}$ \\
\hline
\end{tabular}

Abbreviation: IHC indicates historical cohort, PC Prospective cohort, CS Cross-sectional, BMI body mass index (calculated as weight in kilograms divided by height in meters squared), BF breastfeeding, EBF Exclusive breastfeeding, IOTF the International Obesity Task Force, SES socio-economic status.

${ }^{a}$ The number of participants included in the analysis with different feeding patterns at last follow-up.

${ }^{\mathrm{b}}$ Adjustment for amount of watching TV for children.

${ }^{\mathrm{c}}$ Adjustment for maternal smoking in pregnancy.

obesity with increasing duration of breastfeeding, indicating a change to dose-response effect.

\section{Discussion}

The association between breastfeeding and childhood obesity has long been under debate; however, no agreement has been achieved with respect to this issue. This meta-analysis suggests that breastfeeding protects against obesity in childhood. The risk of childhood obesity was lower in breastfed children by $22 \%$ compared with those who were never breastfed. Meanwhile, a stronger link was found between breastfeeding and obesity based on the crude OR. Two previous meta-analyses have demonstrated that breastfeeding is a protective factor for obesity, but reported inconsistent pooled ORs [23,24]. A change to dose-response effect between breastfeeding duration and childhood obesity was confirmed in our study, in agreement with Harder et al. [25]. In particular, breastfeeding

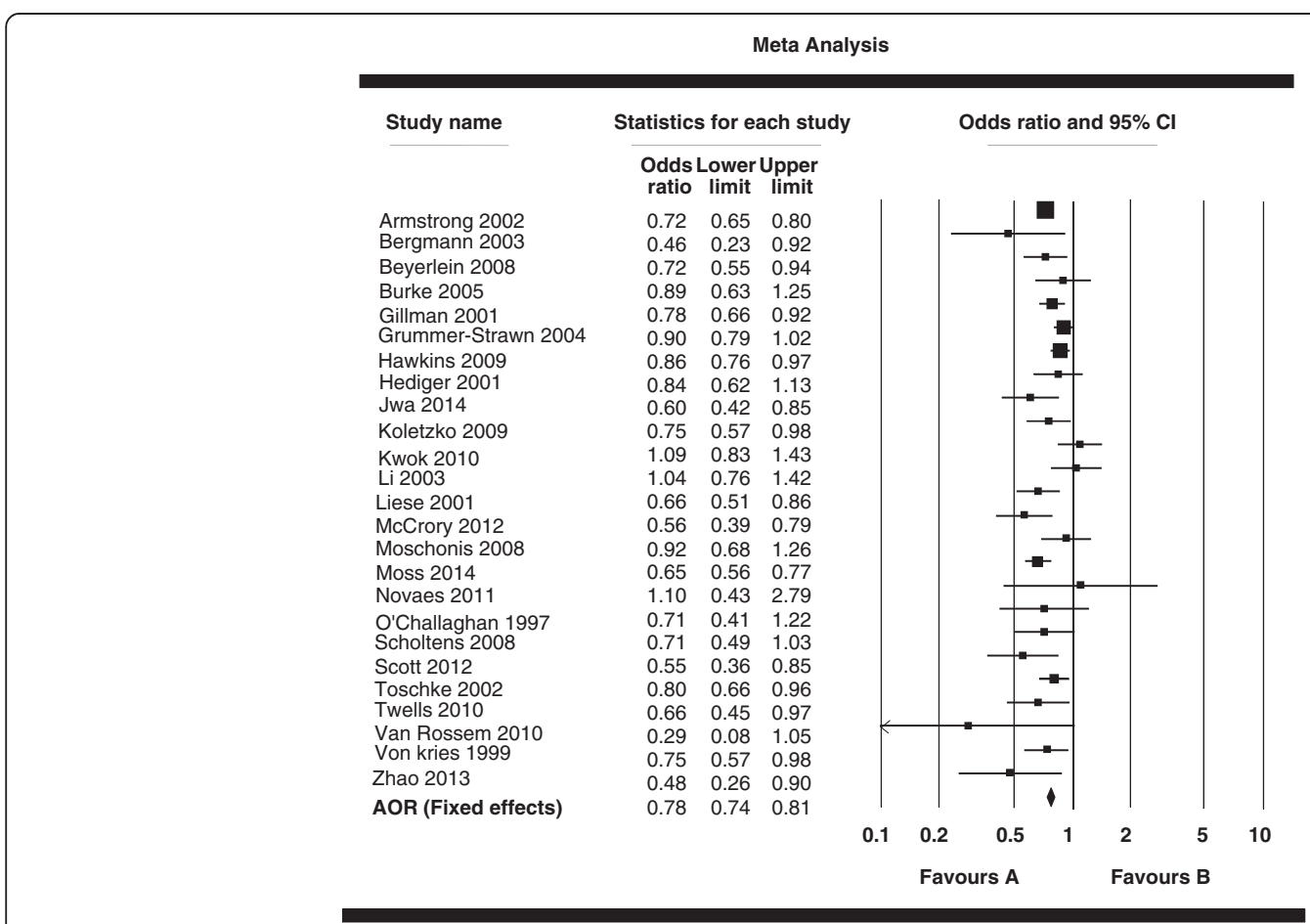

Figure 2 Forest plot of the associations between breastfeeding (never \& ever) and obesity in all 25 studies. Adjusted odds ratios and $95 \%$ confidence intervals. 
Meta Analysis

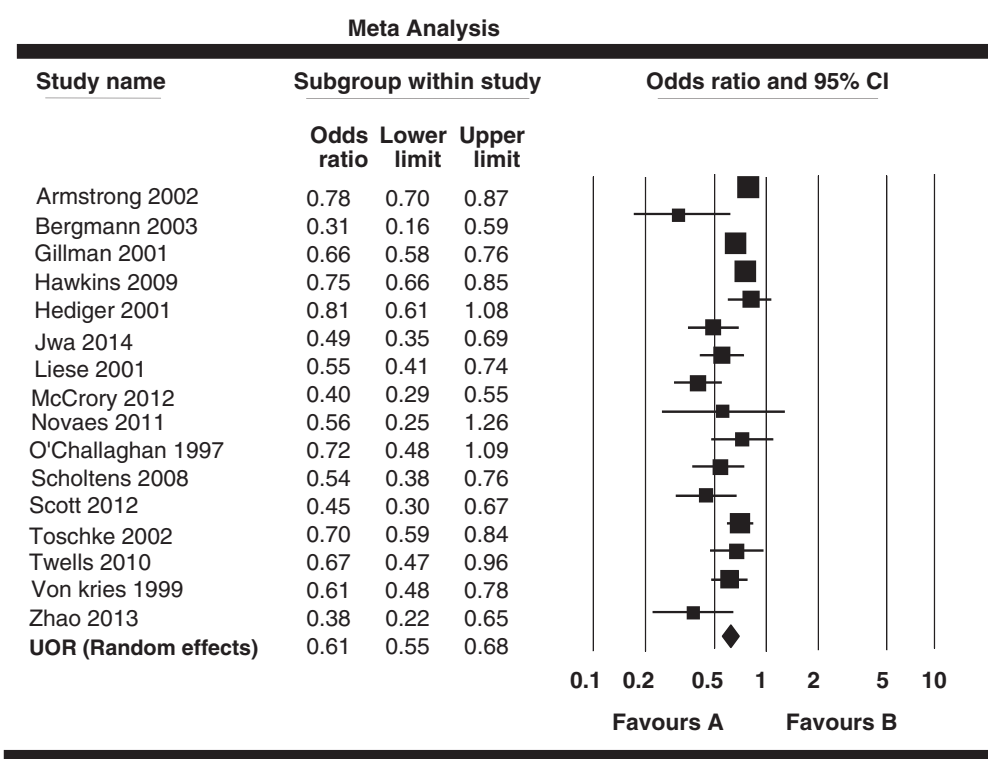

Figure 3 Forest plot of the associations between breastfeeding (never \& ever) and obesity in 16 studies. Unadjusted odds ratios (UOR) and $95 \%$ confidence intervals (CI).

for more than 7 months significantly decreased the risk of obesity [64].

This meta-analysis shows that breastfeeding is a protective factor of adiposity, in contrast to results from several studies, which have shown no link between breastfeeding and obesity [21,22,49]. There are several possible explanations for this finding. First, breast milk provides a moderate amount of calories and nutrients for infant, such as sugar, water, protein and fat [9]. Moreover, the composition of breast milk changes with time and the mother's diet [65]. In contrast, formula feeding provides higher levels of fat and protein than the baby's needs [66]. Higher protein and fat intake in early childhood have been associated with adiposity [67].

Table 2 Findings for subgroup analyses of breastfeeding and childhood obesity

\begin{tabular}{|c|c|c|}
\hline Component & No. of studies (sample size ${ }^{a}$ ) & AOR $(95 \% \mathrm{Cl})$ fixed-effected \\
\hline \multicolumn{3}{|l|}{ Study design } \\
\hline Cohort & $15(141,247)$ & $0.78(0.73,0.82)$ \\
\hline Cross-sectional & $10(85,261)$ & $0.78(0.72,0.84)$ \\
\hline \multicolumn{3}{|c|}{ Whether consider amount of TV viewing and exercise of children as adjusted confounders } \\
\hline Yes & $8(83,356)$ & $0.79(0.73,0.85)$ \\
\hline No & $17(143,152)$ & $0.77(0.73,0.82)$ \\
\hline \multicolumn{3}{|l|}{ Obesity definition } \\
\hline IOTF & $6(73,677)$ & $0.81(0.73,0.89)$ \\
\hline $\mathrm{BMI} \geq 95^{\text {th }}$ & $10(84,557)$ & $0.78(0.74,0.83)$ \\
\hline $\mathrm{BMI} \geq 97^{\text {th }}$ & $5(62,179)$ & $0.75(0.67,0.85)$ \\
\hline Others & $4(6,095)$ & $0.66(0.53,0.82)$ \\
\hline \multicolumn{3}{|l|}{ Breastfeeding definition } \\
\hline Never-ever & $11(126,512)$ & $0.80(0.76,0.85)$ \\
\hline Exposure: breastfeeding duration & $14(99,996)$ & $0.73(0.67,0.79)$ \\
\hline \multicolumn{3}{|l|}{ Breastfeeding type } \\
\hline Exclusive breastfeeding & $8(65,933)$ & $0.80(0.71,0.90)$ \\
\hline Others & $17(160,575)$ & $0.77(0.74,0.81)$ \\
\hline
\end{tabular}

Abbreviation: $\mathrm{Cl}$ confidence interval, $A O R$ adjusted odds ratio.

${ }^{a}$ The total number of subjects for included studies in the analysis at last follow-up. 


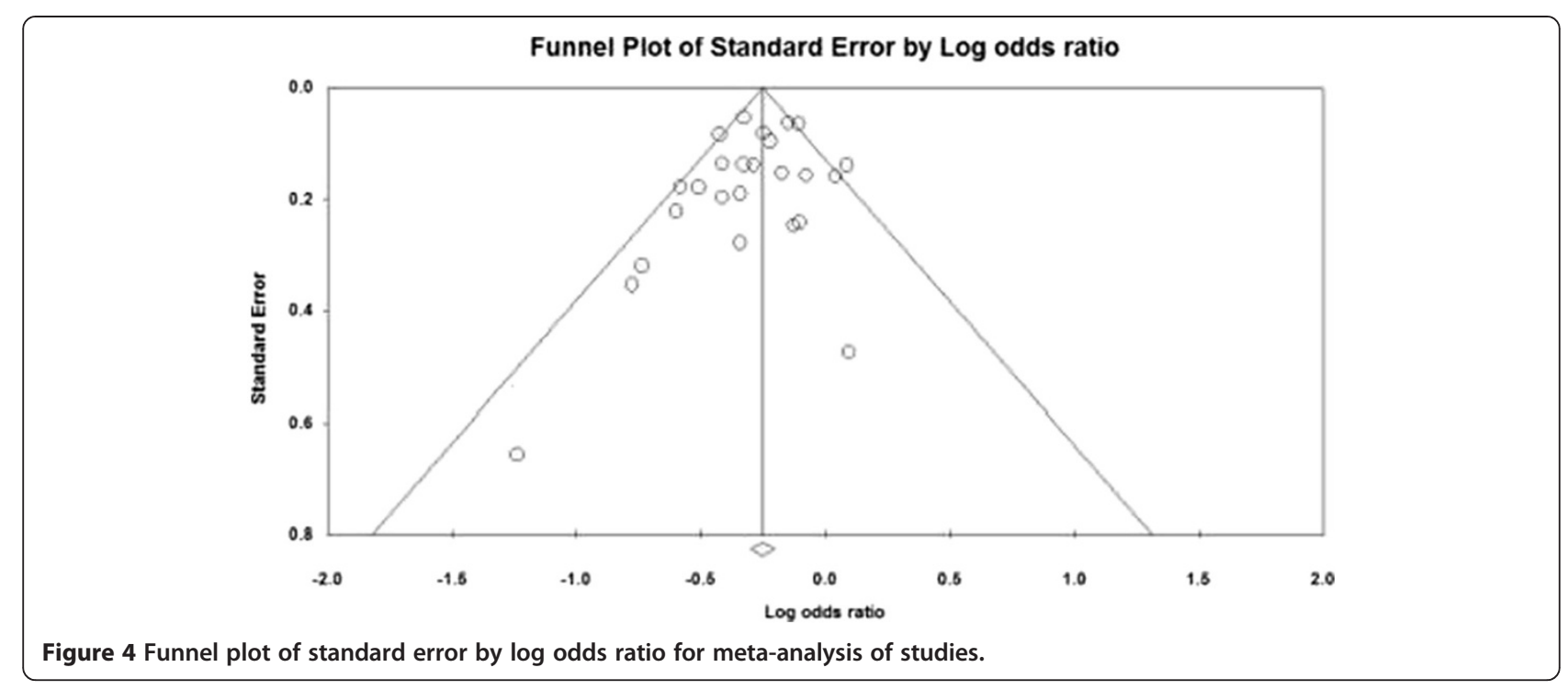

Moreover, breast milk rather than other milk contains bioactive substances such as leptin and ghrelin, which can influence the proliferation and differentiation of the infant's adipocytes $[52,67]$. Thus, breast milk is rich in effective ingredient with higher nutritional value.

Interestingly, many investigations have indicated that breast milk can be influenced by environmental and behavioral factors $[66,67]$. However, several researchers have suggested that unadjusted results should not be ignored either irrespective of the adjusted results [68]. In the present analysis, we compared the pooled ORs before and after combined adjustment for confounders, and observed a decreasing trend after the adjustment for potential confounders. These results support the hypothesis that maternal and individual factors, including genetic, environmental, and behavioral factors, can influence the body shape of children $[45,69]$. Nevertheless, the interaction among multiple factors is still unclear. Factors such as physical activity and screen time (e.g., computer use or TV viewing) are known to significantly affect on the risk of obesity among children $[52,55]$. The subgroup analyses of our study show that breastfeeding was associated with a lower risk of obesity, and the association was independent of TV viewing and exercise level [24]. Therefore, the mechanism(s) by which breastfeeding influences

Table 3 Associations between breastfeeding duration and childhood obesity

\begin{tabular}{lll}
\hline Breastfeeding duration & No. of studies & AOR $(95 \% \mathrm{Cl})$ fixed-effected \\
\hline$<3$ months & 16 & $0.90(0.84,0.95)$ \\
$3-4.9$ months & 8 & $0.88(0.79,0.97)$ \\
$5-6.9$ months & 9 & $0.83(0.76,0.90)$ \\
$\geq 7$ months & 18 & $0.79(0.70,0.88)$ \\
\hline
\end{tabular}

Abbreviation: $\mathrm{Cl}$ confidence interval, $A O R$ adjusted odds ratio. the later life influences the risk of obesity appear to be complex [70].

In addition, stratified analyses revealed differences in obesity definition and breastfeeding definition in the studies we examined. However, it is important to note the smaller sample size in several categories, which may have reduced the statistical power $[23,24]$. The subgroup analyses showed that the association between breastfeeding and childhood obesity was particularly strong in 4 studies that applied other definitions of obesity. The pooled estimates from cross-sectional studies, cohort studies, and studies defining obesity cutoff $\geq 95^{\text {th }}$ were similar to the overall pooled AOR; the pooled estimates from studies using other categories for subgroup analyses were also close to the overall pooled AOR. Moreover, the link between breastfeeding and childhood obesity was slightly different in studies that used different breastfeeding types. This may be because the original data from several studies did not distinguish between exclusive and partial breastfeeding, thereby reducing the precision of our analysis [57,58]. Therefore, future studies should compare the results for exclusive breastfeeding, mixed feeding, and exclusive formula feeding.

A change to dose-response relationship between breastfeeding duration and childhood obesity was confirmed in this study [25]. Breastfeeding for $<3$ months provided a minor protective effect for childhood obesity, while breastfeeding for $\geq 7$ months showed a significantly high protection. These results are inconsistent with the findings of several studies. For example, Toschke et al. reported no association between breastfeeding for $<6$ months and obesity [71]. Similarly, another study found children who were exclusively breastfed for $<4$ months did not have a reduced the risk of obesity [72]. In contrast, McCrory et al. performed a change to dose-response relationship in 
children breastfed for $\geq 4$ weeks and lower risk of obesity [52], and another study showed breastfeeding for 1-16 weeks was associated with a significantly reduced risk of obesity [57]. These discrepancies in the findings may be related to the diverse populations (with unique genetic and environmental backgrounds) and different sample sizes.

This meta-analysis has several strengths. First, it was based on adjusted ORs and 95\% CIs from each study, which largely ruled out residual confounding by other factors and improved the accuracy of the effect estimate. In addition, we analyzed the most recently data published (before $1^{\text {st }}$ August 2014) and historical data, with no lower date limit. Compared to previous reviews $[23,24]$, which reported the pooled AOR, this metaanalysis included a larger sample size, which improved the statistical power. Also, several limitations of this study should be considered. An important limitation is the funnel plot presented an asymmetry; thus, the publication bias cannot be fully ruled out. There are 2 possible explanations for this result. First, among the 25 included studies, 24 were published in English and 1 in Chinese, while other language were not included in this study. It is well accepted that studies showing significant results are more likely to be published, and more likely to be published in English, which is a common cause of publication bias. Although we searched several electronic databases of Chinese to increase the number of studies reported in Chinese in this analysis, none could be added due to the poor quality of reporting. Only 2 of the 25 included papers investigated the Chinese population, and the results from 1 study showed no association between breastfeeding and childhood obesity [49]. Therefore, confirmation of these findings is needed in further research conducted in the Chinese population. Second, we did not consider unpublished investigations that may lead to publication bias. Another limitation of the present analysis is the AORs of each study that were adjusted for different confounders. As well, a weaker association between breastfeeding and obesity was observed after the adjustment of known confounders. Therefore, if we adjust for the same and more relevant confounders, the protective effect of early breastfeeding might reduce largely. However, breastfeeding has been suggested to be a protective factor to childhood obesity in numerous studies [64,73]. Moreover, because several studies did not report the breastfeeding type, we could not distinguish all the collected data between exclusive and partial breastfeeding, and hence, the precision of effect estimates may be influenced. However, the pooled estimate for exclusive breastfeeding was calculated, based on data from 8 studies [46,47,49,53,60-63]. Finally, the different BMI cut-offs using for defining obesity in different studies may also have had an impact on the overall estimate; therefore, we performed a subgroup analysis by obesity definition to minimize this limitation.

\section{Conclusion}

In summary, the aim of this systematic review was to investigate the association between breastfeeding and childhood obesity. The results indicate a protective effect of breastfeeding for childhood obesity, and prolonged breastfeeding is directly related to a decreasing risk of obesity. In particularly, children being breastfed for $\geq 7$ are significantly less likely to be obese in later childhood. Future research should distinguish the data between exclusive breastfeeding, mixed feeding, and exclusive formula feeding, and use uniform potential confounders.

\section{Abbreviations}

IOTF: International Obesity Task Force; WHO: World Health Organization; AOR: Adjusted odds ratio; OR: Odds ratio; BMI: Body mass index;

Cl: Confidence interval; SD: Standard deviations; CDC: Centers of disease control and prevention; IHC: Indicates historical cohort; PC: Prospective cohort; CS: Cross-sectional; BF: Breastfeeding; EBF: Exclusive breastfeeding; SES: Socio-economic status; UOR: Unadjusted odds ratios.

\section{Competing interests}

The authors declare that they have no competing interest.

\section{Authors' contributions}

PPW and GWH contributed to the conception and design of this study. JY and $L L$ were responsible for the data collection and the data analysis. JY drafted the first version of the manuscript. PPW, GWH and ZY subsequently revised the manuscript. All the authors provided final approval.

\section{Authors' information}

PPW is a professor of epidemiology in the Faculty of Medicine of Memorial University of Newfoundland (MUN). GWH is a professor of dietetics/nutrition, and the Dean of the School of Public Health in Tianjin Medical University (TMU). LL and ZC are current Master's students at MUN, while JY is a lecturer at TMU.

\section{Acknowledgements}

We wish to extend our appreciation to all study participants for their cooperation and being part of the success. This research was supported by a grant from the National Science and Technology Support Program (No. 2012BAI02B02). This study was partially supported by Janeway Research Children's Hospital Foundation through a Masters Research Grant to Lin Liu.

\section{Funding sources}

This study is supported by a grant from the National Science and Technology Support Program (No. 2012BAI02B02).

\section{Author details}

'Department of Social Medicine and Health Administration, School of Public Health, Tianjin Medical University, Tianjin, China. ${ }^{2}$ Division of Community Health and Humanities, Faculty of Medicine, Memorial University of Newfoundland, St. John's, Newfoundland and Labrador A1B 3 V6, Canada. ${ }^{3}$ Department of Nutrition and Food Science, School of Public Health, Tianjin Medical University, Tianjin 300070, China. ${ }^{4}$ School of Public Health, Tianjin Medical University, Tianjin, China.

Received: 22 August 2014 Accepted: 8 December 2014

Published: 13 December 2014

\section{References}

1. The International Obesity Taskforce. [http://www.laso.org/iotf/obesity/ obesitytheglobalepidemic/]

2. World Health Organization. [http://www.who.int/mediacentre/factsheets/ fs311/en/]

3. Hesketh KD, Campbell KJ: Interventions to prevent obesity in $0-5$ year olds: an updated systematic review of the literature. Obesity 2010, 18:527-s35. 
4. Weng SF, Redsell SA, Swift JA, Yang M, Glazebrook CP: Systematic review and meta-analyses of risk factors for childhood overweight identifiable during infancy. Arch Dis Child 2012, 97:1091-1026.

5. Huh SY, Rifas-Shiman SL, Taveras EM, Oken E, Gillman MW: Timing of solid food introduction and risk of obesity in preschool-aged children. Pediatrics 2011, 127:e544-e551.

6. Daniels SR: The Consequences of Childhood Overweight and Obesity. Future Child 2006, 16:47-67.

7. World Health Organization. [http://www.who.int/dietphysicalactivity/ childhood/en/]

8. Mohammed H, Vuvor F: Prevalence of childhood overweight/obesity in basic school in Accra. Ghana Med J 2012, 46:124-127.

9. Stolzer JM: Breastfeeding and obesity: a meta-analysis. Open J Prev Med 2011, 1:88-93.

10. Labayen I, Ruiz JR, Ortega FB, Loit HM, Harro J, Villa I, Veidebaum T, Sjostrom M: Exclusive breastfeeding duration and cardiorespiratory fitness in children and adolescents. Am J Clin Nutr 2012, 95:498-505.

11. Garver WS, Newman SB, Gonzales-Pacheco DM, Castillo JJ, Jelinek D, Heidenreich RA, Orlando RA: The genetics of childhood obesity and interaction with dietary macronutrients. Genes Nutr 2013, 8:271-287.

12. Jimenez-Cruz A, Bacardi-Gascon M, Pichardo-Osuna A, Mandujano-Trujillo Z, Castillo-Ruiz O: Infant and toddlers' feeding practices and obesity amongst low-income families in Mexico. Asia Pac J Clin Nutr 2010, 19:316-323.

13. Pate RR, O'Neil JR, Liese AD, Janz KF, Granberg EM, Colabianchi N, Harsha DW, Condrasky MM, O'Neil PM, Lau EY, Taverno Ross SE: Factors associated with development of excessive fatness in children and adolescents: a review of prospective studies. Obes Rev 2013, 14:1-14.

14. Xi B, Wang C, Wu L, Zhang M, Shen Y, Zhao X, Wang X, Mi J: Influence of physical inactivity on associations between single nucleotide polymorphisms and genetic predisposition to childhood obesity. Am J Epidemiol 2011, 173:1256-1262.

15. World Health Organization. [http://www.who.int/topics/breastfeeding/en/]

16. Chivers P, Hands B, Parker H, Bulsara M, Beilin LJ, Kendall GE, Oddy WH: Body mass index, adiposity rebound and early feeding in a longitudinal cohort (Raine study). Int J Obes (Lond) 2010, 34:1169-1176.

17. Ferreira HDS, Vieira EDF, Junior CRC, Queiroz MDR: Breastfeeding for 30 days or more is a protective factor against overweight in preschool children. Rev Assoc Med Bras 2010, 56:74-80.

18. Labayen I, Ortega FB, Ruiz JR, Loit HM, Harro J, Villa I, Veidebaum T, Sjöström M: Association of exclusive breastfeeding duration and fibrinogen levels in childhood and adolescence. Arch Pediatr Adolesc Med 2012, 166:56-61.

19. Metzger MW, McDade TW: Breastfeeding as obesity prevention in the United States: a sibling difference model. Am J Hum Biol 2010, 22:291-296.

20. Rzehak P, Sausenthaler S, Koletzko S, Bauer CP, Schaaf B, Von Berg A, Berdel D, Borte $M$, Herbarth $\mathrm{O}$, Krämer U, Fenske N, Wichmann HE, Heinrich J: Period-specific growth, overweight and modification by breastfeeding in the GINI and LISA birth cohorts up to age 6 years. Eur J Epidemio/ 2009, 24:449-467.

21. Burdette HL, Whitaker RC, Hall WC, Daniels SR: Breastfeeding, introduction of complementary foods, and adiposity at $5 \mathrm{y}$ of age. Am J Clin Nutr 2006, 83:550-558.

22. Gillman MW, Rifas-Shiman SL, Kleinman K, Oken E, Rich-Edwards JW, Taveras EM: Developmental origins of childhood overweight: potential public health impact. Obesity 2008, 16:1651-1656.

23. Arenz S, Ruckerl R, Koletzko B, Von Kries R: Breastfeeding and childhood obesity -- a systematic review. Int J Obes (Lond) 2004, 28:1247-1256.

24. Owen CG, Martin RM, Whincup PH, Smith GD, Cook DG: Effect of infant feeding on the risk of obesity across the life course: a quantitative review of published evidence. American Academy of Pediatrics 2005 115:1367-1377.

25. Harder T, Bergmann R, Kallischnigg G, Plagemann A: Duration of breastfeeding and risk of overweight: a meta-analysis. Am J Epidemiol 2005, 162:397-403

26. UNICEF UK. [http://www.unicef.org.uk/babyfriendly/about-baby-friendly/ breastfeeding-in-the-uk/uk-breastfeeding-rates/]

27. All-China Women's Federation. [http://www.womenofchina.cn/html/ womenofchina/report/173045-1.htm]

28. Chinn S: Definitions of childhood obesity: current practice. Eur J Clin Nutr 2006, 60:1189-1194.
29. Rolland-Cachera MF: Childhood obesity: current definitions and recommendations for their use. Int J Pediatr Obes 2011, 6:325-331.

30. Cole TJ, Bellizzi MC, Flegal KM, Dietz WH: Establishing a standard definition for child overweight and obesity worldwide: international survey. BMJ 2000, 320:1240-1243.

31. Bowden J, Tierney JF, Copas AJ, Burdett S: Quantifying, displaying and accounting for heterogeneity in the meta-analysis of RCTs using standard and generalized Q statistics. BioMed Central 2011, 11:41-52.

32. Huedi-Medina TB, Sanchez-Meca J, Marin-Martinez F, Botella J: Assessing heterogeneity in meta-analysis: Q statistic or $\mathrm{I}^{2}$ index? Psychol Methods 2006, 11:193-230

33. Zheng H, Orsini N, Amin J, Wolk A, Nguyen VT, Ehrlich F: Quantifying the dose-response of walking in reducing coronary heart disease risk: meta-analysis. Eur J Epidemio/ 2009, 24:181-192.

34. Bax L, Moons KG: Beyond publication bias. J Clin Epidemiol 2011, 64:459-462.

35. Dubben HH, Beck-Bornholdt HP: Systematic review of publication bias in studies on publication bias. BioMed Central 2005, 331:433-434

36. Macaskill P, Walter SD, Irwig L: A comparison of methods to detect publication bias in meta-analysis. Stat Med 2001, 20:641-654.

37. Peters $J$, Sutton AJ, Jones DR, Abrams KR, Rushton L: Comparison of two methods to detect publication bias in meta-analysis. Am Med Assoc 2006, 295:676-680.

38. Rucker G, Schwarzer G, Carpenter J: Arcsine test for publication bias in meta-analyses with binary outcomes. Stat Med 2008, 27:746-763.

39. Armstrong J, Reilly JJ: Breastfeeding and lowering the risk of childhood obesity. Lancet 2002, 359:2003-2004.

40. Bergmann KE, Bergmann RL, Von Kries R, Böhm O, Richter R, Dudenhausem JW, Wahn U: Early determinants of childhood overweight and adiposity in a birth cohort study: role of breast-feeding. Int J Obes Relat Metab Bisord 2003, 27:162-72.

41. Beyerlein A, Toschke AM, Kries RV: Breastfeeding and childhood obesity: shift of the entire BMI distribution or only the upper parts? Obesity 2008 16:2730-2733

42. Burke V, Beilin LJ, Simmer K, Oddy WH, Blake KV, Doherty D, Kendll GE, Newnham JP, Louis LI, Stanley FJ: Breastfeeding and overweight: longitudinal analysis in an Australian birth cohort. J Pediatr 2005, 147:56-61.

43. Gillman MW, Rifas-Shiman SL, Camargo CA, Berkey CS, Frazier AL, Rockett $\mathrm{HRH}$, Field AE, Colditz CA: Risk of overweight among adolescents who were breastfed as infants. JAMA 2001, 285:2461-2467.

44. Grummer-Strawn LM, Mei Z: Does breastfeeding protect against pediatric overweight? Analysis of longitudinal data from the centers for disease control and prevention pediatric nutrition surveillance system. Pediatrics 2004, 113:e81-e86.

45. Hawkins SS, Cole TJ, Law C: An ecological systems approach to examining risk factors for early childhood overweight: findings from the UK Millennium Cohort Study. J Epidemiol Community Health 2009, 63:147-155.

46. Hediger ML, Overpeck MD, Kuezmarski RJ, Ruan WJ: Association between infant breastfeeding and overweight in young children. JAMA 2001, 285:2453-2460.

47. Jwa SC, Fujiwara T, Kondo N: Latent protective effects of breastfeeding on late childhood overweight and obesity: a nationwide prospective study. Obesity 2014, 22:1527-1537.

48. Koletzko B, Von Kries R, Closa R, Escribano J, Scaglioni S, Giovannini M, Beyer J, Demmelmair H, Anton B, Gruszfeld D, Dobrzanska A, Sengier A, Langhendries JP, Rolland Cachera MF, Grote V: Can infant feeding choices modulate later obesity risk? Am J Clin Nutr 2009, 89:1502S-1508S.

49. Kwok MK, Schooling CM, Lam TH, Leung GM: Does breastfeeding protect against childhood overweight? Hong Kong's 'children of 1997' birth cohort. Int J Epidemiol 2010, 39:297-305.

50. Li L, Parsons TJ, Power C: Breast feeding and obesity in childhood: cross sectional study. BMJ 2003, 327:904-905.

51. Liese AD, Hirsch T, Von Mutius E, Keil U, Leupold W, Weiland SK: Inverse association of overweight and breast feeding in 9 to 10-y-old children in Germany. Int J Obes Relat Metab Disord 2001, 25:1664-1650.

52. McCrory C, Layte R: Breastfeeding and risk of overweight and obesity at nine-years of age. Soc Sci Med 2012, 75:323-330.

53. Moschonis G, Grammatikaki E, Manios Y: Perinatal predictors of overweight at infancy and preschool childhood: the GENESIS study. Int J Obes (Lond) 2008, 32:39-47. 
54. Moss BG, Yeaton WH: Early childhood healthy and obese weight status: potentially protective benefits of breastfeeding and delaying solid foods. Matern Child Health J 2013, 18:1224-1232.

55. Novaes JF, Lamounier JA, Colosimo EA, Franceschini SC, Priore SE: Breastfeeding and obesity in Brazilian children. Eur J Public Health 2011, 22:383-389.

56. O'Callaghan MJ, Williams GM, Andersen MJ, Bor W, Najman JM: Prediction of obesity in children at 5 years: a cohort study. J Paediatr Child Health 1997, 33:311-316.

57. Scholtens S, Brunekreef B, Smit HA, Gast GCM, Hoekstra MO, De Jongste JC, Postma DS, Gerritsen J, Seidell JC, Wijga AH: Do differences in childhood diet explain the reduced overweight risk in breastfed children? Obesity 2008, 16:2498-2503.

58. Scott JA, Ng SY, Cobiac L: The relationship between breastfeeding and weight status in a national sample of Australian children and adolescents. BMC Public Health 2012, 12:107-112.

59. Toschke AM, Vignerova J, Lhotska L, Osancova K, Koletzko B, Von Kries R: Overweight and obesity in 6- and 14-year-old Czech children in 1991: protective effect of breast-feeding. J Pediatr 2002, 141:764-769.

60. Twells L, Newhook LA: Can exclusive breastfeeding reduce the likelihood of childhood obesity in some regions of Canada? Can J Public Health 2010, 101:36-39.

61. Van Rossem L, Taveras EM, Gillman MW, Kleinman KP, Rifas-Shiman SL, Raat H, Oken E: Is the association of breastfeeding with child obesity explained by infant weight change? Int J Pediatr Obes 2011, 6:e415-e422.

62. Von Kries R, Koletzko B, Sauerwald T, Von Mutius E, Barnert D, Grunert V, Von Voss H: Breast feeding and obesity: cross sectional study. BMJ 1999, 319:147-150.

63. Zhao YL, Ma RM, Huang YK, Liang K, Ding ZB: Effect of breastfeeding on childhood overweight in the offspring of mothers with gestational diabetes mellitus. Chin J Contemp Pediatr 2013, 15:56-61.

64. Kramer MS, Matush L, Vanilovich I, Platt RW, Bogdanovich N, Sevkovskaya Z, Dzikovich I, Shishko G, Collet JP, Martin RM, Davey-Smith G, Gillman MW Chalmers B, Hodnett E, Shapiro S: Effects of prolonged and exclusive breastfeeding on child height, weight, adiposity, and blood pressure at age 6.5 y: evidence from a large randomized trial. Am J Clin Nutr 2007, 86:1717-1721.

65. World Health Organization: Long-term effects of breastfeeding: a systematic review. Geneva: World Health Organization; 2013.

66. Agostoni C, Braegger C, Decsi T, Kolacek S, Koletzko B, Michaelsen KF, Mihatsch W, Moreno LA, Puntis J, Shamir R, Szajewska H, Turck D, van Goudoever J: Breast-feeding: A Commentary by the ESPGHAN Committee on Nutrition. J Pediatr Gastroenterol Nutr 2009, 49:112-125.

67. Hernell $\mathrm{O}$ : Human milk vs cow's milk and the evolution of infant formulas. Nestle Nutr Workshop Ser Pediatr Program 2011, 67:17-28.

68. Buchan IE, Heller RF, Bundred PE, Cole TJ: Early life risk factors for obesity in childhood: early feeding is crucial target for preventing obesity in children. BMJ 2005, 331:453-454.

69. Grummer-Strawn LM, Scanlon KS, Fein SB: Infant feeding and feeding transitions during the first year of life. Pediatrics 2008, 122:S36-\$42.

70. Li R, Fein SB, Grummer-Strawn LM: Do infants fed from bottles lack selfregulation of milk intake compared with directly breastfed infants? Pediatrics 2010, 125:e1386-e1393.

71. Toschke AM, Martin RM, von Kries R, Wells J, Smith GD, Ness AR: Infant feeding method and obesity: body mass index and dual-energy X-ray absorptiometry measurements at 9-10 y of age from the Avon Longitudinal Study of Parents and Children (ALSPAC). Am J Clin Nutr 2007, 5:1578-1585.

72. Huus K, Ludvigsson JF, Enskär K, Ludvigsson J: Exclusive breastfeeding of Swedish children and its possible influence on the development of obesity: a prospective cohort study. BMC Pediatr 2008, 8:42-47.

73. Yang Z, Huffman SL: Nutrition in pregnancy and early childhood and associations with obesity in developing countries. Maternal Child Nutr 2013, 9:105-119.

doi:10.1186/1471-2458-14-1267

Cite this article as: Yan et al:: The association between breastfeeding and childhood obesity: a meta-analysis. BMC Public Health 2014 14:1267.

\section{Submit your next manuscript to BioMed Central and take full advantage of:}

- Convenient online submission

- Thorough peer review

- No space constraints or color figure charges

- Immediate publication on acceptance

- Inclusion in PubMed, CAS, Scopus and Google Scholar

- Research which is freely available for redistribution

Submit your manuscript at www.biomedcentral.com/submit
C BioMed Central 